\title{
TIME HEADWAY ANALYSIS TO DETERMINE THE ROAD CAPACITY
}

\author{
I Wayan Suweda ${ }^{1}$
}

\begin{abstract}
In developed countries, road capacity values derived from time headway is in accordance to their local traffic characteristics. In theory, time headway standards are developed using statistics models. These standards however, are not necessarily relevant to use in Indonesia. This is because of the differences in traffic conditions and motorists behaviours between those in developed countries and Indonesia. This study is to develop the time headway distribution model and subsequently to determine lionk-road capacity in the city of Denpasar, Bali Province. The study consists of time headway data analysis, model calibration and validation and road capacity values determination. The study found that normal distribution model fitted the local traffic conditions. Road capacity values are of 2,466 pcus/hour and 2,900 pcus/hour obtained from time headway model and the Indonesian Road Capacity Manual (MKJI) respectively.
\end{abstract}

Keywords: time headway distribution model, mixed traffic, road capacity

ABSTRAK: Di negara maju, nilai-nilai kapasitas jalan ditentukan berdasarkan waktu headway sesuai dengan karakteristik lalu lintas lokal. Secara teori, standar waktu headway dikembangkan menggunakan model-model statistik. Standar-standar ini tentunya tidak selalu relevan untuk digunakan di Indonesia. Hal ini karena perbedaan kondisi lalu lintas dan perilaku pengendara antara mereka yang di negara-negara maju dan Indonesia. Penelitian ini dimaksudkan untuk mengembangkan model distribusi waktu headway dan selanjutnya dipergunakan untuk menentukan kapasitas segmen-jalan di kota Denpasar, Provinsi Bali. Penelitian ini terdiri dari analisis data waktu headway, kalibrasi dan validasi model dan menemukan nilai kapasitas jalan. Dari hasil studi ditemukan bahwa model distribusi normal cocok untuk kondisi lalu lintas lokal. Sedangkan, nilai kapasitas jalan adalah $2.466 \mathrm{smp} / \mathrm{jam}$ dan $2.900 \mathrm{smp} /$ jam yang berturut-turut diperoleh berdasarkan model waktu headway dan Manual Kapasitas Jalan Indonesia (MKJI).

Kata-kata kunci: model distribusi waktu headway, lalu lintas campuran, kapasitas jalan

\footnotetext{
${ }^{1}$ Dosen Program Studi Magister Teknik Sipil, Program Pascasarjana Universitas Udayana
} 


\section{INTRODUCTION}

Transportation system variables including road capacity and level of services, motorist behaviours and traffic safety are strongly influenced by motor vehicle time headway (Sukowati, 2004 and Minh, et al. 2005). Salter in 1976 defined time headway is a time difference between the sequences of motor vehicles passing a certain point on a road lane. Minimum time headway is a measure of traffic safety level for the vehicle if a vehicle in front suddenly decelerating or braking. Meanwhile, time headway distribution is a measure of road level of service because it measures of a motor vehicle for passing, merging and crossing with the other vehicles. Road capacity is determined by time headway minimum value and distributions based the relationship between capacity and traffic flow (Tiwari, 2000).

In theory, traffic flow concepts and its derivatives used in Indonesia are developed from countries such as USA, UK and Australia. Those are composed considering homogeneous traffic flow conditions dominated by light vehicles. In facts, the Indonesian Road Capacity Manual (as known as MKJI 1997) uses passenger cars (light vehicles) as a standard conversion to the other modes. Traffic volumes and road capacity are estimated using number of road lanes on the assumption that oncoming vehicles run and stopped consistently on a lane.

On mixed traffic which are very common in all Indonesian cities, motorcycles and both heavy and light vehicles however, share roadways together. Many vehicles, in particular motorcycles, are not run on the road lanes. Road capacity determination using the number of road lanes as a standard therefore, may produce an imprecise result (Tiwari, 2000). Motorcycles may reduce the speed of other vehicles behind and in turn contribute to traffic delay as they run next to each other on the road (Minh, et al. 2005). These certainly reduce the road level of service.

Road capacity determination in accordance to local traffic conditions therefore, is more relevant to apply in Indonesia. This is because the differences of traffic characteristics and motorist behaviours between those in developed countries and Indonesia. The existing standard time headway in Indonesia remains in line to those homogeneous traffic conditions as in developed countries (Tiwari, 2000). A study on time headway considering mixed traffic conditions therefore, is important to conduct.
Investigation on time headway reflecting mixed traffic conditions in Indonesia has not much been done. A previous study conducted in Semarang, Central Java, studying on time headway and road capacity determination on both toll and non-toll roads (Sukowati, 2004). It did not include however, the influence of motorcycle on time headway and road capacity. This study objectives are to develop the time headway distribution model and determine road capacity values by taking into account all modes including motorcycles. The study is expected to reflect the real conditions of both mixed traffic and time headway and its influence on the road capacity in the city of Denpasar.

\section{MODELLING TIME HEADWAY \\ 2.1 Calibration and Validation of Time Headway Distribution Model}

Road capacity can be determined using standard time headway between vehicles. More specifically, road capacity can be analysed using average time headway per unit of traffic flow. Time headway is made up of occupancy time and time gap. As described by May in 1990, the time period of occupancy is physically a vehicle passing a point of observation, while time gap is a time difference between the rear of the vehicle in front and the front end of the vehicle to follow passing through the same point of observation (Sukowati, 2004).

Time headway distribution has long been studied for which the main objectives were to analyse road capacity, road safety and the number of vehicles on microscopic simulation (Al-Ghamdi, 2001). Time headway varied in accordance with traffic volume. In a low traffic volume where less interaction between vehicles, time headways were randomly distributed. Meanwhile, in high and medium traffic volumes, time headway distribution is constant and mixed (between random and constant) respectively. May in 1990 concluded that negative exponential, normal distribution and Pearson Type III models are relevant to random, constant and mixed time headway distributions respectively (Sukowati, 2004). A previous study conducted in Saudi Arabia concluded that the gamma distribution and shifted exponential models can represent time headway for low and medium traffic volumes (Al-Ghamdi, 2001). In addition, it was suggested that no time headway data can be 
combined from different places to obtain an appropriate distribution model.

In order to validate the model, the following steps are taken:

a. Data collected from each location should be statistically sufficient as the minimum increase is of 100-200 vehicles per hour.

b. Chi-square test method is sufficiently be used to test the distribution models and is expressed as follows:

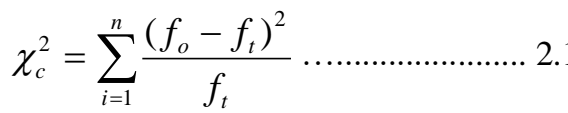

where,

$$
\begin{array}{rll}
f_{o} & =\text { Observed data frequency } \\
f_{t} & =\text { Theoretical data frequency } \\
\chi_{c}^{2} & =\text { Calculated value of chi }
\end{array}
$$

Using these previous studies (Sukowati, 2004 and Al-Ghamdi, 2001). time headway

\begin{tabular}{|c|c|c|c|c|}
\hline $\begin{array}{c}\text { Traffic } \\
\text { Volume }\end{array}$ & $\begin{array}{l}\text { Vehicles } \\
\text { Numbers }\end{array}$ & $\begin{array}{c}\text { Time } \\
\text { Headway }\end{array}$ & $\begin{array}{c}\text { Approrpiate } \\
\text { Models }\end{array}$ & Function \\
\hline Low & $<400 \mathrm{vehs} / \mathrm{h}$ & $>9$ seconds & $\begin{array}{l}\text { Negative } \\
\text { Eksponential }\end{array}$ & $\chi e^{-\lambda t}$ \\
\hline Medium & 400-1.200 vehs/h & 2,5-9 seconds & $\begin{array}{l}\text { Pearson } \\
\text { Type III }\end{array}$ & $\frac{\pi}{[\Gamma(\mathrm{K})]}[\lambda(t-\alpha)]^{\mathrm{K}-1} e^{-\lambda(t-\alpha)}$ \\
\hline High & $>1.200 \mathrm{vehs} / \mathrm{h}$ & $<2,5$ seconds & $\begin{array}{l}\text { Normal } \\
\text { Distribution }\end{array}$ & $\frac{z}{s}$ \\
\hline
\end{tabular}
distribution models can be classified as shown in Table 2.1.

Table 2.1 Time Headway Distribution Model Classification

\subsection{Road Capacity Determination Using MKJI 1997 and Time Headway}

The maximum road capacity is the road ability passing vehicles per unit time under normal road and traffic circumstances (Department of Public Works, 1997). There are several factors that strongly affect the road capacity as follows:

a. Road factors include lane width, lateral freedom, road shoulders, median, road surface conditions, road alignment, road flatness and footways.

b. Traffic factors include traffic composition, traffic volume, lane distribution, traffic disruption and side frictions.

c. Environmental factors include pedestrians, cyclists, and animals.

Road capacity can be determined using the formula as follows (Department of Public Works, 1997):
$\mathrm{C}=\mathrm{C}_{\mathrm{o}} \cdot \mathrm{FC}_{\mathrm{W}} \cdot \mathrm{FC}_{\mathrm{SP}} \cdot \mathrm{FC}_{\mathrm{SF}} \cdot \mathrm{FC}_{\mathrm{CS}}$

Where:

C = Road capacity (pcu/hour)

$\mathrm{C}_{\mathrm{o}} \quad=$ Basic capacity (pcu/hour)

$\mathrm{FC}_{\mathrm{W}}=$ Adjustment factor for road width

$\mathrm{FC}_{\mathrm{SP}}=$ Adjustment factor for traffic separation

$\mathrm{FC}_{\mathrm{SF}}=$ Adjustment factor for side friction

$\mathrm{FC}_{\mathrm{CS}}=$ Adjustment factor for city size

In order to calculate the Passenger Car Units (pcu) for all modes in the city of Denpasar, this study uses Passenger Car Equivalent (PCE) for urban areas (Department of Public Works, 1997) as shown in Table 2.2. 
Table 2.2 Passenger Car Equivalent (PCE) for Urban Road

\begin{tabular}{|c|c|c|c|c|}
\hline \multirow{4}{*}{ Road types } & \multirow{4}{*}{$\begin{array}{c}\text { Traffic Flows } \\
\text { (two ways) } \\
\text { (veh/hour) }\end{array}$} & \multicolumn{3}{|c|}{ Passenger Car Equivalent } \\
\hline & & \multirow{3}{*}{ Heavy Vehicles } & \multirow{2}{*}{\multicolumn{2}{|c|}{$\begin{array}{c}\text { Motorcycles } \\
\text { Road width, Wc (m) }\end{array}$}} \\
\hline & & & & \\
\hline & & & $\leq 6$ & $>6$ \\
\hline \multirow{2}{*}{$\begin{array}{l}\text { Two lanes two ways } \\
\text { undivided ( } 2 / 2 \text { UD) }\end{array}$} & 0 up to 1,800 & 1.3 & 0.5 & 0.4 \\
\hline & $\geq 1,800$ & 1.2 & 0.35 & 0.25 \\
\hline \multirow{2}{*}{$\begin{array}{l}\text { Four lanes two ways } \\
\text { undivided ( } 4 / 2 \text { UD) }\end{array}$} & 0 up to 3,700 & 1.3 & \multicolumn{2}{|c|}{0.4} \\
\hline & $\geq 3,700$ & 1.2 & \multicolumn{2}{|c|}{0.25} \\
\hline
\end{tabular}

Two types of traffic data required to estimate a cross-sectional road capacity are traffic volume and time headway (Minderhoud et al. 1997). In addition, some information including traffic density and average traffic speed are very helpful. For instance, traffic speed data is useful to analyse traffic conditions such as traffic stability and traffic jams. As traffic density (number of vehicles per kilometer of the road) increases, the average speed decreases and the traffic becomes unstable afterward. This can suddenly turn into traffic congestion where speeds decrease while densities increase. Such a heavy traffic flow (the average speed drops below a certain value) means that the level of capacity has been accomplished in a bottleneck situation itself. In this condition it is possible to estimate a more reliable capacity. Steady traffic flow can occur when a driver can maintain the desired speed.

Time headway is defined as the time between successive vehicles that passing a certain point in the path of traffic flow. The formula is expressed as follows (Sukowati, 2004):

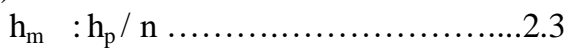$$
\mathrm{Q} \quad: \mathrm{n} / \mathrm{T}=1 / \mathrm{h}_{\mathrm{m}} \ldots \ldots \ldots \ldots \ldots \ldots . .2 .4
$$

where:

$\mathrm{h}_{\mathrm{p}}=$ Time Headway of a vehicle (p) to a vehicle in front (second/vehicle)

$\mathrm{h}_{\mathrm{m}}=$ Average Time Headway (second/veh)

$\mathrm{Q}=$ Road Capacity (vehicle/second)

$\mathrm{n}=$ Total Number of Vehicles Passing a

Certain Point of Observation during period of $\mathrm{T}$.
The central value of statistics consisting average (mean), midpoint (median), highest frequency (mode) and percentile values are intensively used to determine the road capacity (Sukowati, 2004). Percentile value is defined as a measure used to indicate a percentage value under a group of data. For example, 90 percentiles indicate values that are below the $90 \%$ of the observational data.

\section{CASE STUDY AREA AND DATA DESCRIPTIONS \\ 3.1 Case Study Area}

The data used in this study is adopted from a previous study conducted in the city of Denpasar (Sudarsana, 2013). The study investigated Passenger Cars Equivalent (PCE) determination by making use of time headway analysis. However, it did not examine time headway distribution model and road capacity.

The case study area as shown in Figure 3.1 is located in the city of Denpasar on Sesetan Road segment. More specifically, it is situated between the intersection of Sesetan Road Pulau Saelus Road and the intersection of Sesetan Road - Pulau Buton Road. This has 9 meters and 1.2 meters of road width and shoulder respectively and is classified as two lanes two ways of undivided road segment $(2 / 2$ UD).

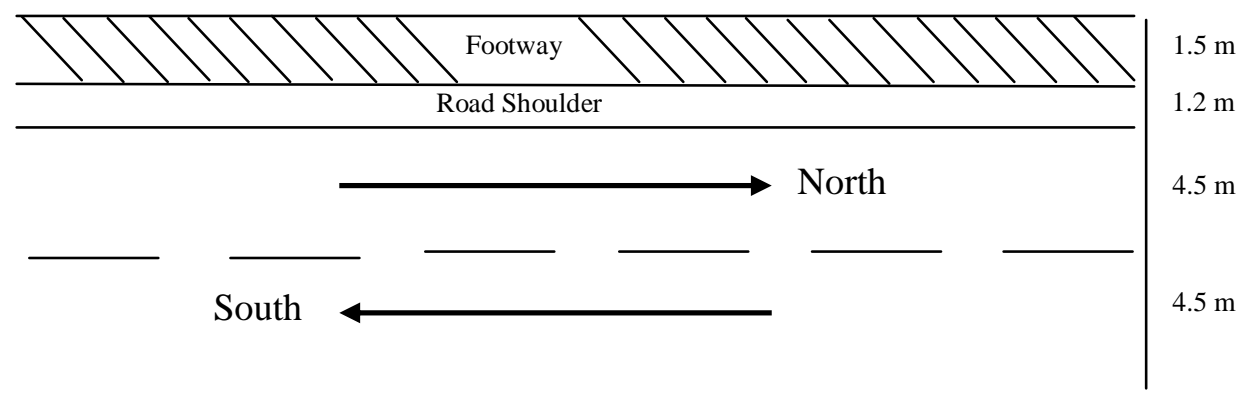




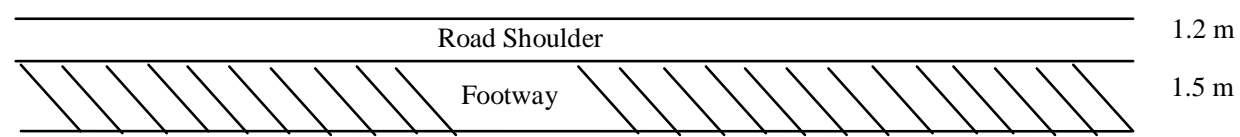

Figure 3.1 Case Study Area

The selected road segment has low side frictions (no on street parking, low pedestrian crossings and non motorised transport, low in and out movements from the surrounding land uses). In addition, this road has been experiencing high mixed traffic volume. This road segment therefore, is considered relevant to be used in this study.

\subsection{Data Descriptions}

Traffic volume and time headway data were collected using digital video recording on Wednesday 1 May 2013 between 04.00 a.m. to 04.00 p.m. (Sudarsana, 2013). Traffic volume data consists all modes i.e. motorcycles (MC), heavy and light vehicles (HV and LV).

Table 3.1 Traffic Volume Proportion

\begin{tabular}{|l|c|c|}
\hline $\begin{array}{c}\text { Modes of } \\
\text { Transport }\end{array}$ & $\begin{array}{c}\text { Total } \\
(\text { Vehs/h) }\end{array}$ & $\begin{array}{c}\text { Proportion } \\
(\%)\end{array}$ \\
\hline Motorcycles & 42,881 & 83.14 \\
\hline Light Vehicles & 8,176 & 15.85 \\
\hline Heavy Vehicles & 523 & 1.01 \\
\hline
\end{tabular}

As shown in Table 3.1, motorcycles dominated the traffic in which they were accounted for by $83 \%$ of total modes.

Following division on urban road (Department of Public Works, 1997), traffic volume data are classified into two (2) groups consisting total volumes for $<1800$ vehicles/hour and for $\geq 1800$ vehicles/hour. By using a standard PCE shown in Table 2.2, traffic volume is expressed in PCU as shown in Table 3.2. The proportion of motorcycles, light and heavy vehicles and motorcycles of total traffic flow for $<1800$ vehicles/hour are $71 \%$, $27 \%$, and $2 \%$ respectively. Meanwhile, the proportion of motorcycles, light and heavy vehicles and motorcycles are 55\%, $42 \%$ and $3 \%$ of total traffic flow for $\geq 1800$ vehicles/hour. It can be seen that the proportion of heavy vehicles is relatively stable during the observation period. During daytime, motorcycles decreased by $26 \%$ while in contrast, light vehicles increased by $15 \%$. .

Table 3.2 Traffic Volume

\begin{tabular}{|c|c|c|c|c|c|c|c|c|}
\hline \multicolumn{9}{|c|}{ Total traffic flow for $<1800$ vehicles/hour } \\
\hline & \multicolumn{4}{|c|}{ Volume (vehicles/hour) } & \multicolumn{4}{|c|}{ Volume (pcu/hour) } \\
\hline Time & LV & $\mathrm{HV}$ & $\mathrm{MC}$ & Total & LV & $\mathrm{HV}$ & $\mathrm{MC}$ & Total \\
\hline $04.00-05.00$ & 162 & 14 & 910 & 1,086 & 162 & 18.2 & 364 & 544 \\
\hline $05.00-06.00$ & 40 & 0 & 432 & 472 & 40 & 0 & 172.8 & 213 \\
\hline & & & & 1,558 & & & & 757 \\
\hline
\end{tabular}

\begin{tabular}{|c|c|c|c|c|c|c|c|c|}
\hline \multicolumn{9}{|c|}{ Total traffic flow for $\geq 1800$ vehicles/hour } \\
\hline & \multicolumn{4}{|c|}{ Volume (vehicles/hour) } & \multicolumn{4}{|c|}{ Volume (pcu/hour) } \\
\hline Time & LV & $\mathrm{HV}$ & MC & Total & LV & $\mathrm{HV}$ & MC & Total \\
\hline 06.00-07.00 & 648 & 38 & 4,608 & 5,294 & 648 & 46 & 1,152 & 1,846 \\
\hline 07.00-08.00 & 648 & 36 & 4,687 & 5,371 & 648 & 43 & 1,172 & 1,863 \\
\hline 08.00-09.00 & 731 & 48 & 3,972 & 4,751 & 731 & 58 & 993 & 1,782 \\
\hline 09.00-10.00 & 584 & 48 & 3,963 & 4,595 & 584 & 58 & 991 & 1,632 \\
\hline $10.00-11.00$ & 582 & 49 & 3,556 & 4,187 & 582 & 59 & 889 & 1,530 \\
\hline $11.00-12.00$ & 967 & 64 & 3,687 & 4,718 & 967 & 77 & 922 & 1,966 \\
\hline $12.00-13.00$ & 828 & 52 & 4,153 & 5,033 & 828 & 62 & 1,038 & 1,929 \\
\hline $13.00-14.00$ & 942 & 47 & 3,864 & 4,853 & 942 & 56 & 966 & 1,964 \\
\hline $14.00-15.00$ & 948 & 65 & 3,772 & 4,785 & 948 & 78 & 943 & 1,969 \\
\hline $15.00-16.00$ & 917 & 49 & 3,882 & 4,848 & 917 & 59 & 971 & 1,947 \\
\hline & & & & 48,435 & & & & 18,428 \\
\hline
\end{tabular}


Meanwhile, there are eight (8) pairs of time headway measured as shown in Table 3.3.

Table 3.3 Pair of Time Headway Observation

\begin{tabular}{|c|l|c|l|}
\hline No. & Pair of Time Headway & No. & Pair of Time Headway \\
\hline 1. & Between MC and MC & 5. & Between HV and HV \\
\hline 2. & Between LV and MC & 6. & Between LV and HV \\
\hline 3. & Between MC and LV & 7. & Between LV and LV \\
\hline 4. & Between LV and LV & 8. & Between HV and MC \\
\hline
\end{tabular}

Each pair of time headway is calculated when the vehicle's front wheel touches the point of observation to the next vehicle's front wheels touched the same observation point. All pairs of time headway however, can not be calculated so that some criteria are used to sample it. These criteria require each pair should really look unhindered another vehicle when front wheel passes the observation point and each pair is really a sequentially vehicle. Time headway data is shown in Table 3.4.

Table 3.4 Time Headway

\begin{tabular}{|c|c|c|c|c|c|c|c|c|}
\hline \multicolumn{8}{|c|}{ Total Traffic Flows of < 1800 vehicles/hour } \\
\hline & MC-MC & LV-MC & MC-LV & LV-LV & HV-HV & LV-HV & LV-LV & HV-MC \\
\hline $\begin{array}{c}\text { No. } \\
\text { Observation }\end{array}$ & 28 & 28 & 28 & 84 & 7 & 7 & 7 & 21 \\
\hline $\begin{array}{c}\text { Average } \\
\text { seconds) }\end{array}$ & 0.19 & 0.26 & 0.03 & 0.88 & 2.61 & 2.50 & 0.50 & 1.73 \\
\hline \multicolumn{7}{|c|}{ Total Traffic Flows of $\geq 1800$ vehicles/hour } \\
\hline $\begin{array}{c}\text { No. } \\
\text { Observation }\end{array}$ & 211 & 211 & 211 & 633 & 143 & 143 & 143 & 380 \\
\hline $\begin{array}{c}\text { Average } \\
\text { seconds) }\end{array}$ & 0.06 & 0.19 & 0.04 & 0.51 & 2.32 & 0.21 & 0.17 & 1.06 \\
\hline
\end{tabular}

Table 3.4 shows that the lowest time headway (0.06 second) is among motorcycles during daytime (traffic flows for $\geq 1800$ vehicles/hour). This indicates that motorcyclist behaviours such as speeding and manoeuvring among vehicles to get ahead during the congested road exist in such a typical mixed traffic.

\section{MODEL DEVELOPMENT}

\subsection{Model Calibration}

Time headway data may be classified into several classes according to Sturgis's rules (number of classes $=1+3.3 \times \log n$, where $n$ is the number of data). For example, the time headway of traffic flow for $\geq 1800$ vehicles/hour is divided into 11 classes $(1+3.3$ $x \log$ 1968). Data range for each class is constructed by trial and error so that the expected frequency probability approaching 1 while considering time headway below 2.5 seconds has very large data variations. This has to be done because of considerable large frequency; the statistical model may have a particular significant bias in determining the expected/theoretical frequency. The results may not subsequently be relevant to the normal distribution model. In fact, time headway frequency sufficiently proves that the road segment has saturated flows. Time headway frequency distribution is shown in Table 4.1.

Table 4.1 Time Headway Frequency Distribution 


\begin{tabular}{|c|c|}
\hline Total traffic flow for $<1800$ vehicles/hour & Total traffic flow for $\geq 1800$ vehicles/hour \\
\hline Frequency (average \& standard deviation) & Frequency (average \& standard deviation $)$ \\
\hline $206(0.60$ seconds; 0.80 second $)$ & $1968(0.53$ second; 1,18 seconds $)$ \\
\hline
\end{tabular}

The average time headway of the total flows for $<1800$ vehicles/hour and for $\geq 1800$ vehicles/hour are 0.60 second and 0.53 second respectively. As shown in Table 4.1, the road segment experiences high traffic flow while time headway is normally distributed. Time headway distribution therefore, is calibrated using Normal Distribution Model which is suitable for high traffic flows. The appropriate model is determined using the normal distribution density function as expressed in equation 4.1, below. The normal distribution model calculations are shown in Table 4.2.

$\mathrm{Z}_{1}=\frac{x_{b}-\mu}{\sigma}$ and $\mathrm{Z}_{2}=\frac{x_{a}-\mu}{\sigma}$

where:

$\mathrm{X}_{\mathrm{a}, \mathrm{b}}=$ Upper and Lower Interval

Boundaries

$\mu$

= Average time headway $\sigma=$ Standard deviation

$\mathrm{Z}_{1}, \mathrm{Z}_{2}=\mathrm{Z}$ value for lower and upper boundary

Table 4.2 shows the calculation of both $\mathrm{Z}_{1}$ and $\mathrm{Z}_{2}$ to determine the expected frequency for the group of total traffic flow for $\geq 1800$ vehicles/hour. Each probability $\left(\mathrm{P}_{1}\right.$ and $\left.\mathrm{P}_{2}\right)$ of these values are determined using the Normal Distribution table. The sum of both probabilities is multiplied with observed time headway frequency $\left(f_{o}\right)$ to obtain the expected time headway frequency $\left(\mathrm{f}_{\mathrm{t}}\right)$. These steps are also applied to determine the expected frequency of total traffic flow group for $<1800$ vehicles/hour. The observed and expected frequency distributions are validated by the chisquare method to determine the suitability of the model.

Table 4.2 Expected Frequency of Total traffic flow for $\geq 1800$ Vehicles/Hour

\begin{tabular}{|c|c|c|c|c|c|c|r|}
\hline $\begin{array}{c}\text { Lower and Upper } \\
\text { Boundary }\end{array}$ & $\mathrm{f}_{\mathrm{o}}$ & $\mathrm{Z}_{1}$ & $\mathrm{Z}_{2}$ & $\mathrm{P}_{1}$ & $\mathrm{P}_{2}$ & $\mathrm{P}_{1}+\mathrm{P}_{2}$ & $\mathrm{f}_{\mathrm{t}}$ \\
\hline $0.00-0.06$ & 923 & -3.0000 & 3.0000 & 0.4987 & 0.4987 & 0.9973 & 921 \\
\hline $0.07-0.11$ & 272 & -2.0000 & 2.0000 & 0.4772 & 0.4772 & 0.9545 & 260 \\
\hline $0.12-0.16$ & 88 & -2.0000 & 2.0000 & 0.4772 & 0.4772 & 0.9545 & 84 \\
\hline $0.17-0.21$ & 43 & -2.0000 & 2.0000 & 0.4772 & 0.4772 & 0.9545 & 41 \\
\hline $0.22-0.73$ & 246 & -1.9231 & 2.0000 & 0.4728 & 0.4772 & 0.9500 & 234 \\
\hline $0.74-1.50$ & 194 & -1.5000 & 1.6667 & 0.4332 & 0.4522 & 0.8854 & 172 \\
\hline $1.51-2.50$ & 104 & -0.9600 & 2.6400 & 0.3315 & 0.4959 & 0.8273 & 94 \\
\hline $2.51-3.75$ & 48 & -1.4571 & 2.0857 & 0.4275 & 0.4815 & 0.9090 & 44 \\
\hline $3.76-5.01$ & 19 & -1.77 & 1.139535 & 0.4614 & 0.3728 & 0.8342 & 16 \\
\hline $5.02-7.52$ & 21 & -1.6849 & 1.7397 & 0.4540 & 0.4590 & 0.9130 & 19 \\
\hline $7.53-10.9$ & 10 & -1.9550 & 1.0811 & 0.4747 & 0.3602 & 0.8349 & 8 \\
\hline
\end{tabular}

\subsection{Model Validation}

The developed model has to be validated to analyse goodness of fit between the observation and theoretical data. Chi square $\left(\chi^{2}\right)$ test were used to performed such analysis. The criteria used are as follows:

a. Hypothesis is accepted if $\chi_{\mathrm{c}}<\chi_{\text {table }}$, and

b. Hypothesis is rejected if $\chi_{\mathrm{c}}>\chi_{\text {table }}$. where $\chi_{\mathrm{c}}$ and $\chi_{\text {table }}$ are obtained from equation 2.1 and chi square table respectively. Hypothesis test is expressed as:

a. Ho: $\mathrm{f}_{\mathrm{t}}=$ fo, and

b. Ha: $f_{t} \neq$ fo.

Where,

Ho and Ha are Null and Alternate Hypotheses respectively.

Table 4.3 Chi Square Test of Total traffic flow for $\geq 1800$ vehicles/hour

\begin{tabular}{|c|c|c|c|c|c|}
\hline \multicolumn{5}{|c|}{ Total traffic flow for $\geq 1800$ vehicles/hour } \\
\hline Interval (seconds) & fo & $\mathrm{ft}$ & fo- $\mathrm{ft}$ & $(\text { fo- } \mathrm{ft})^{2}$ & $(\mathrm{fo}-\mathrm{ft})^{2} / \mathrm{ft}$ \\
\hline
\end{tabular}




\begin{tabular}{|c|c|c|c|c|c|}
\hline $0.00-0.06$ & 923 & 921 & 2 & 6 & 0.01 \\
\hline $0.07-0.11$ & 272 & 260 & 12 & 153 & 0.59 \\
\hline $0.12-0.16$ & 88 & 84 & 4 & 16 & 0.19 \\
\hline $0.17-0.21$ & 43 & 41 & 2 & 4 & 0.09 \\
\hline $0.22-0.73$ & 246 & 234 & 12 & 151 & 0.65 \\
\hline $0.74-1.50$ & 194 & 172 & 22 & 494 & 2.88 \\
\hline $1.51-2.50$ & 104 & 94 & 10 & 100 & 1.06 \\
\hline $2.51-3.75$ & 48 & 44 & 4 & 19 & 0.44 \\
\hline $3.76-5.01$ & 19 & 16 & 3 & 10 & 0.63 \\
\hline $5.02-7.52$ & 21 & 19 & 2 & 3 & 0.17 \\
\hline $7.53-10.9$ & 10 & 8 & 2 & 3 & 0.33 \\
\hline & & & $\chi_{\mathrm{c}}=$ & 7.03 \\
\hline
\end{tabular}

Table 4.4 Chi Square Test of Total traffic flow for $<1800$ vehs/hour

\begin{tabular}{|c|c|c|c|c|c|}
\hline \multicolumn{6}{|c|}{ Total traffic flow for $<1800$ vehicles/hour } \\
\hline Interval (seconds) & fo & $\mathrm{ft}$ & fo-ft & $(\text { fo- } \mathrm{ft})^{2}$ & $(\mathrm{fo}-\mathrm{ft})^{2} / \mathrm{ft}$ \\
\hline $0.00-0.04$ & 60 & 57 & 3 & 7 & 0.13 \\
\hline $0.05-0.09$ & 23 & 22 & 1 & 1 & 0.05 \\
\hline $0.10-0.14$ & 8 & 5 & 3 & 6 & 1.18 \\
\hline $0.15-0.19$ & 11 & 8 & 3 & 12 & 1.62 \\
\hline $0.20-0.49$ & 26 & 23 & 3 & 8 & 0.34 \\
\hline $0.50-0.99$ & 34 & 30 & 4 & 16 & 0.53 \\
\hline $1.00-2.00$ & 27 & 22 & 5 & 28 & 1.28 \\
\hline $2.01-2.98$ & 17 & 9 & 8 & 62 & 6.77 \\
\hline \multirow{2}{*}{\multicolumn{5}{|c|}{$\mathrm{n}=8, \mathrm{df}=6, \alpha=5 \%, \chi$ table $=$}} & 11.91 \\
\hline & & & & & 12.59 \\
\hline \multicolumn{5}{|c|}{ Hypothesis } & Accepted \\
\hline
\end{tabular}

Table 4.3 shows the comparison between theoretical and observed time headway data. It can be seen that between the observed and expected time headway data are statistically related.

\section{ROAD CAPACITY DETERMINATION}

Road capacity is determined using descriptive statistics values consisting mean, median and mode of time headway distribution
(Sukowati, 2004). The mean, median and modus are calculated from observed and theoretical distribution models. For example, 90 percentile of total traffic flows of $\geq 1800$ vehicles/hour indicates that $90 \%$ of time headway is less than 1.54 seconds as shown in Table 5.1.

Table 5.1 Central Values (in seconds)

Observed Data Distributions

\begin{tabular}{|c|c|c|c|c|c|c|c|}
\hline \multicolumn{2}{|c|}{ Total traffic flow for $<1800$ vehicles/hour } & \multicolumn{4}{c|}{ Total traffic flow for $\geq 1800$ vehicles/hour } \\
\hline Mean & Median & Modus & 90 percentiles & Mean & Median & Modus & 90 percentiles \\
\hline 0,60 & 0,2 & 0,01 & 1,80 & 0,53 & 0,07 & 0,02 & 1,54 \\
\hline & & & & & & & \\
\hline
\end{tabular}

Theoretical Data Distributions

\begin{tabular}{|c|c|c|c|c|c|c|c|}
\hline \multicolumn{3}{|c|}{ Total traffic flow for $<1800$ vehicles/hour } & \multicolumn{4}{c|}{ Total traffic flow for $\geq 1800$ vehicles/hour } \\
\hline Mean & Median & Modus & 90 percentiles & Mean & Median & Modus & 90 percentiles \\
\hline 0.52 & 0.17 & 0.01 & 1.58 & 0.50 & 0.07 & 0.02 & 1.46 \\
\hline
\end{tabular}


Applying equation (2.3) and (2.4), the road capacity can be calculated using time headway values in Table 5.1. The results are shown in Table 5.2. The highest capacity is achieved when modus values are used. These however, cannot be directly used to determine road capacity. They should be compared with the basic road capacity value.

Table 5.2 Road Capacity (pcu/hour)

\begin{tabular}{|c|c|c|c|c|c|c|c|}
\hline \multicolumn{8}{|c|}{ Observed Data Distributions } \\
\hline \multicolumn{4}{|c|}{ Total traffic flow for $<1800$ vehicles/hour } & \multicolumn{4}{|c|}{ Total traffic flow for $\geq 1800$ vehicles/hour } \\
\hline Mean & Median & Modus & $\begin{array}{c}90 \\
\text { percentiles }\end{array}$ & Mean & Median & Modus & $\begin{array}{c}90 \\
\text { percentiles }\end{array}$ \\
\hline 6,000 & 18,000 & 360,000 & 2,000 & 6,792 & 51,429 & 180,000 & 2,338 \\
\hline \multicolumn{8}{|c|}{ Theoretical Data Distributions } \\
\hline \multicolumn{4}{|c|}{ Total traffic flow for $<1800$ vehicles/hour } & \multicolumn{4}{|c|}{ Total traffic flow for $\geq 1800$ vehicles/hour } \\
\hline Mean & Median & Modus & $\begin{array}{c}90 \\
\text { percentiles }\end{array}$ & Mean & Median & Modus & $\begin{array}{c}90 \\
\text { percentiles }\end{array}$ \\
\hline 6,988 & 21,818 & 360,000 & 2,278 & 7,262 & 51,429 & 180,000 & 2,466 \\
\hline
\end{tabular}

In equation 2.2, it is expressed that road capacity is a function of the basic capacity. The basic capacity of road segment for both directions is of 2,900 pcus/hour. Passenger car equivalent however, is used to obtain this basic road capacity value. This value will certainly be different when motorcycle equivalent is used to value the basic road capacity. In fact, motorcycle is accounted for by $90 \%$ of total modes in Denpasar (Statistics of Bali Province, 2013). In order to do so, further studies therefore, are recommended. As shown in Table 5.2 , the 90 percentiles value is of 2,466 pcus/hour that is the closest value to the basic road capacity. Subsequently, this is considered to be road capacity value using time headway method.

\section{CONCLUSIONS}

Time headway and traffic conditions on Sesetan Road are well fitted by a normal distribution model. This is because such a road segment experienced heavy traffic flow. The road capacity values obtained from time headway distribution and the Indonesian Road Capacity Manual are of 2,466 pcus/hour and 2,900 pcus/hour respectively. Further studies may be conducted by recording time headway for each pair of vehicles and traffic volume during a certain interval. Such data can be used to determine road capacity by constructing the relationship between time headway and traffic volume. Instead of passenger car equivalent, the subsequent studies may use motorcycles equivalent. This is because motorcycles have the largest proportion in mixed traffic. The motorcycle equivalent value should be determined in advance before time headway analysis.

\section{REFERENCES}

Al-Ghamdi, A. S (2001). Analysis of Time Headways on Urban Roads: Case Study from Riyadh, Journal of Transportation Engineering, Vol. 127, No. 4, pp. 289-294.

Department of Public Works, (1997). The Indonesian Road Capacity Manual.

May, A. D. (1990). Traffic Flow Fundamentals, Prentice-Hall Inc., Englewood Cliffs, New Jersey.

Minderhoud, M.M., Botma, H. and Bovy, P.H.L (1997). Assessment of Roadway Capacity Estimation Methods, Transportation Research Record 1572, pp. 59-67.

Minh, C.C., Sano, K. and Matsumoto, S (2005). The Speed, Flow and Headway Analyses of Motorcycle Traffic, Journal of the Eastern Asia Society for Transportation Studies, Vol. 6, pp. 1496 - 1508.

Salter, R. J (1976). Highway Traffic Analysis and Design, Second edition, Macmillan Education Ltd., London.

Statistics of Bali Province. Bali in Figure. (2013).

Sudarsana, I.G.P.(2013). The Determination of Passenger Car Equivalent on Urban Road Link using Time Headway Ratio Method, Unpublished Final Project, Department of Civil Engineering, Faculty of Engineering, Udayana University, Bali. 
Sukowati, D.G (2004). Time Headway Vehicle Characteristics on Toll and Non Toll Roads (Case Study Section B Toll Road Semarang and Demak Ring Road ), Unpublished Thesis, Postgraduate Program, The University of Diponegoro Semarang.
Tiwari, G. (2000). Traffic Flow and Safety: Need for New Models for Heterogeneous Traffic, Injury Prevention and Control, pp. 71-88. 